\title{
Effects of Ginger and Its Constituents on Airway Smooth Muscle Relaxation and Calcium Regulation
}

\author{
Elizabeth A. Townsend1, Matthew E. Siviski ${ }^{1}$, Yi Zhang1, Carrie Xu1 , Bhupinder Hoonjan², \\ and Charles W. Emala' \\ ${ }^{1}$ Department of Anesthesiology, Columbia University Medical Center, Columbia University, New York, New York; and ${ }^{2}$ Barts and The London School \\ of Medicine and Dentistry, Queen Mary University, London, United Kingdom
}

The prevalence of asthma has increased in recent years, and is characterized by airway hyperresponsiveness and inflammation. Many patients report using alternative therapies to self-treat asthma symptoms as adjuncts to short-acting and long-acting $\beta$-agonists and inhaled corticosteroids (ICS). As many as $40 \%$ of patients with asthma use herbal therapies to manage asthma symptoms, often without proven efficacy or known mechanisms of action. Therefore, investigations of both the therapeutic and possible detrimental effects of isolated components of herbal treatments on the airway are important. We hypothesized that ginger and its active components induce bronchodilation by modulating intracellular calcium $\left(\left[\mathrm{Ca}^{2+}\right]_{i}\right)$ in airway smooth muscle (ASM). In isolated human ASM, ginger caused significant and rapid relaxation. Four purified constituents of ginger were subsequently tested for ASM relaxant properties in both guinea pig and human tracheas: [6]-gingerol, [8]-gingerol, and [6]-shogaol induced rapid relaxation of precontracted ASM (100$300 \mu \mathrm{M})$, whereas [10]-gingerol failed to induce relaxation. In human ASM cells, exposure to [6]-gingerol, [8]-gingerol, and [6]shogaol, but not [10]-gingerol $(100 \mu \mathrm{M})$, blunted subsequent $\mathrm{Ca}^{2+}$ responses to bradykinin $(10 \mu \mathrm{M})$ and $\mathrm{S}-(-)$-Bay K $8644(10 \mu \mathrm{M})$. In $A / J$ mice, the nebulization of [8]-gingerol $(100 \mu \mathrm{M}), 15$ minutes before methacholine challenge, significantly attenuated airway resistance, compared with vehicle. Taken together, these novel data show that ginger and its isolated active components, [6]-gingerol, [8]-gingerol, and [6]-shogaol, relax ASM, and [8]-gingerol attenuates airway hyperresponsiveness, in part by altering $\left[\mathrm{Ca}^{2+}\right]_{i}$ regulation. These purified compounds may provide a therapeutic option alone or in combination with accepted therapeutics, including $\beta_{2}$-agonists, in airway diseases such as asthma.

Keywords: asthma; lung; herbal; botanica; bronchodilation

The prevalence of asthma has steadily increased in recent years, and is characterized by bronchoconstriction, increased airway hyperresponsiveness, and inflammation of the airways. In addition to traditional asthma therapies, namely, short-acting and long-acting $\beta$-agonists and inhaled corticosteroids (ICS), many patients report using complementary and alternative medicine (CAM) to self-treat their asthma symptoms. Recent studies found that $60 \%$ of patients with moderate asthma and $70 \%$ of patients with severe asthma use CAM (1). Herbal remedies are among the top therapies used among CAM proponents.

(Received in original form June 28, 2012 and in final form September 21, 2012)

This work was supported by National Institutes of Health grants GM065281 (C.W.E.) and GM008464 (E.A.T.).

Correspondence and requests for reprints should be addressed to Elizabeth Townsend, Ph.D., Department of Anesthesiology, Columbia University Medica Center, 650 West 168th Street, Black Building 7-713, New York, NY 10032. E-mail: et2413@columbia.edu

This article has an online supplement, which is accessible from this issue's table of contents at www.atsjournals.org

Am J Respir Cell Mol Biol Vol 48, Iss. 2, pp 157-163, Feb 2013

Copyright $\odot 2013$ by the American Thoracic Society

Originally Published in Press as DOI: 10.1165/rcmb.2012-02310C on October 11, 2012

Internet address: www.atsjournals.org
Natural plant products in the forms of teas, topical ointments, and dietary supplements have received accolades for the relief of respiratory ailments, including cough and bronchospasm (2-5). As many as $40 \%$ of patients with asthma are estimated to use herbal therapies to self-treat their asthma symptoms $(6,7)$. The exact mechanism of action of these agents is unclear, but may involve the attenuation of allergic responses (i.e., IgE concentrations) (8), anti-inflammatory and antioxidant effects (5), or direct effects on airway smooth muscle (ASM) $(9,10)$. Of note is the use of ginger in alleviating respiratory symptoms, dyspepsia, and gastrointestinal motility disorders (11-13). Previously recognized similarities between gut smooth muscle and ASM, taken together with the anecdotal use of ginger in relieving these symptoms, suggest that ginger and its constituents may exert direct effects on ASM. Furthermore, we hypothesize that purified components of crude ginger, namely, [6]-gingerol, [8]-gingerol, [10]-gingerol, and [6]-shogaol, will relax airway smooth muscle and potentially serve as novel bronchodilators.

Airway tone is regulated by ASM and represents a balance between contractile and relaxant signaling inputs. In diseases such as asthma, the hypercontractile phenotype is partly attributable to an imbalance in these inputs (i.e., excessive constriction and impaired dilation). Airway smooth muscle contraction is regulated, in part, by intracellular calcium $\left(\left[\mathrm{Ca}^{2+}\right]_{\mathrm{i}}\right)$. As such, we set forth to examine the effects of ginger and its active components on airway tone and the mechanisms of $\left[\mathrm{Ca}^{2+}\right]_{i}$ regulation in ASM cells. By better understanding the mechanisms through which purified components of ginger exert their effects on the airway, we can explore the use of these naturally derived phytotherapeutics in alleviating asthma symptoms. This may lead to the development of safer and more efficacious herbal therapies that gain clinical acceptance and increase adherence to herbal and classic therapies in patients choosing to self-treat with CAM. In the present study, we hypothesized that ginger and its active components (14-16) induce bronchodilation by modulating $\left[\mathrm{Ca}^{2+}\right]_{\mathrm{i}}$ in ASM.

\section{MATERIALS AND METHODS}

Detailed methods are presented in the online supplement.

\section{Cultured Human Airway Smooth Muscle Cells}

Immortalized and primary human ASM cell lines were prepared as described previously $(17,18)$ and grown in phenol red-free Dulbecco's Modified Eagle's Medium/F12 media (GIBCO, Grand Island, NY), with $10 \%$ FBS and antibiotics.

\section{Guinea Pig Tracheal Rings}

Animal protocols were approved by the Animal Care and Use Committee of Columbia University. Male guinea pigs were anesthetized, and their tracheas were removed. Epithelial-denuded tracheal rings were prepared as previously described (19). The rings were suspended in jacketed organ baths, bubbled with a gas mixture of $95 \%$ oxygen and $5 \%$ carbon dioxide, and refreshed every 15 minutes for 1 hour during equilibration of the tracheal rings at $1 \mathrm{~g}$ resting tension. 


\section{Human Tracheal Strips}

Experiments using human surgical waste tissue (deidentified from healthy, normal organ donors) were reviewed by the Institutional Review Board of Columbia University and deemed admissible as "not human subjects research." Smooth muscle tissue was carefully dissected, and the epithelia were removed. The strips were anchored in the organ bath, as described in the online supplement.

\section{Preliminary Contractile Challenges}

Please see the online supplement for details.

\section{Measurement of $\left[\mathrm{Ca}^{2+}\right]_{i}$}

Black-walled, clear-bottomed 96-well plates containing human ASM cells were incubated with the ratiometric calcium indicator Fura-2 AM $(5 \mu \mathrm{M})$ with $0.05 \%$ Pluronic F-127 (both from Life Technologies, Grand Island, NY) and $2.5 \mathrm{mM}$ probenecid in Hanks' balanced salt solution for 30 minutes at $37^{\circ} \mathrm{C}$. The cells were washed and then excited $(340 / 380 \mathrm{~nm})$ continuously at $20 \mathrm{~Hz}$, and emission data were collected at $510 \mathrm{~nm}$, using a FlexStation 3 microplate reader (Molecular Devices, Sunnyvale, CA).

\section{Inositol Phosphate Assays}

The synthesis of total $\left[{ }^{3} \mathrm{H}\right]$-inositol phosphates was measured in immortalized human ASM cells, as previously described $(20,21)$.

\section{Airway Resistance Measurements}

Animal protocols were approved by the Animal Care and Use Committee of Columbia University. Male A/J mice were anesthetized with an intraperitoneal injection of Fatal Plus $(10 \mathrm{mg} / \mathrm{kg}$ pentobarbital; Vortech Pharmaceuticals, Dearborn, MI), and the mice were mechanically ventilated with an FX1 module (Flexivent; SCIREQ, Montreal, Quebec, Canada). Three baseline measurements were performed, followed by pretreatment with either vehicle control (0.1\% DMSO in PBS) or $100 \mu \mathrm{M}$ [8]-gingerol, delivered via a 10 -second nebulization. After 15 minutes of default ventilation, murine airway resistance was then measured in response to increasing doses of methacholine (Sigma-Aldrich, St. Louis, MO).

\section{Statistical Analysis}

Fifteen guinea pigs, 10 human samples, and 25 mice were used for these experiments. However, not all protocols were performed in each animal or sample. Values indicated in the REsults and figure legends represent the numbers of animals or tissue samples. Calcium imaging data were performed in more than 100 cells, and each of these experimental permutations was performed on at least four different passages of human ASM cells. The values for cellular data represent the numbers of days on which the experiments were performed. Data were analyzed using unpaired $t$ tests or one-way ANOVA with repeated measures when appropriate. The Bonferroni correction was applied for multiple comparisons. Statistical significance was established at $P<0.05$, and all values are expressed as means $\pm \mathrm{SE}$.

\section{Materials}

All materials were obtained from Sigma-Aldrich (St. Louis, MO), unless otherwise specified in the online supplement.

\section{RESULTS}

\section{Crude Ginger Relaxes Human Airway Smooth Muscle}

Normal human tracheas with epithelia removed were suspended in the organ bath and contracted with acetylcholine (ACh) (approximate half maximal effective concentration $\left.\left[\sim \mathrm{EC}_{50}\right]\right)$. Upon stable force generation, increasing amounts of food-grade ginger powder (0.5 mg, $1 \mathrm{mg}, 5 \mathrm{mg}, 10 \mathrm{mg}, 25 \mathrm{mg}, 50 \mathrm{mg}$, and $100 \mathrm{mg}$ ) suspended in $1 \mathrm{ml}$ of water were added to the Krebs-Henseleit buffer, and water was used as vehicle control. A dose-dependent relaxation was observed, with the most substantial relaxation occurring with 50 and $100 \mathrm{mg} / \mathrm{ml}$ (Figure 1A). After 30 minutes, relaxation of approximately $70 \%$ was observed in the ginger-treated ASM strips. The midrange dose of $50 \mathrm{mg} / \mathrm{ml}$ food-grade ginger was used in subsequent studies comparing food-grade ginger to its isolated components. These studies were repeated in human tracheas obtained from 4-7 different donors. However, not all compounds were tested in each sample.

\section{Isolated Components of Ginger Significantly Relax Human and Guinea Pig ASM}

The individual components of ginger, [6]-gingerol, [8]-gingerol, and [10]-gingerol, as well as [6]-shogaol $(100 \mu \mathrm{M})$, were examined in contractile studies for their ability to relax ASM precontracted with $\mathrm{ACh}$, compared with $50 \mathrm{mg} / \mathrm{ml}$ food-grade ginger. In human ASM with epithelium removed, [6]-gingerol, [8]-gingerol, and [6]-shogaol, but not [10]-gingerol, induced significant relaxation

A
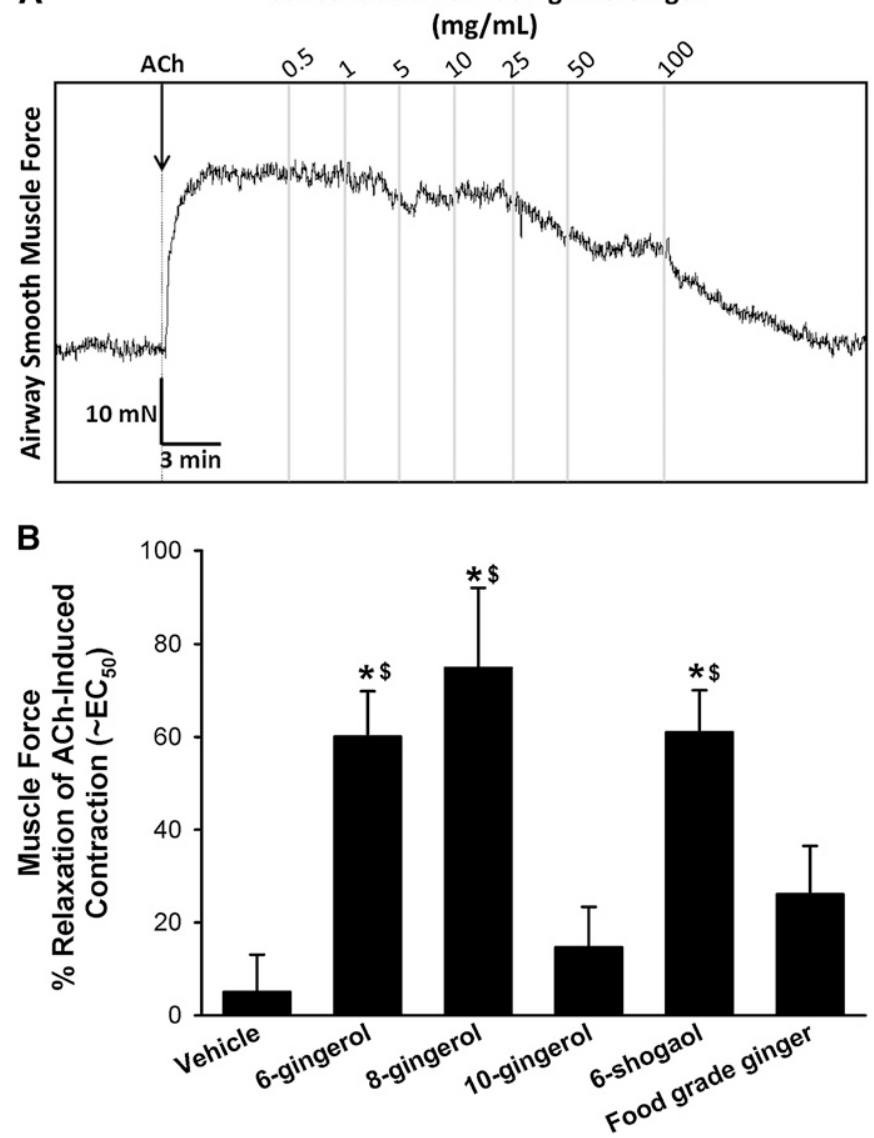

Figure 1. Ginger and its active constituents relax precontracted human airway smooth muscle. $(A)$ Force studies in human airway smooth muscle show that food-grade ginger relaxes precontracted airways in a dosedependent manner. Human tracheal strips were contracted to acetylcholine (ACh) at approximately half maximal concentration $\left(\sim \mathrm{EC}_{50}\right)$, and showed rapid and substantial relaxation upon increasing concentrations of foodgrade ginger. In subsequent studies, only the $50 \mathrm{mg} / \mathrm{ml}$ concentration was used. (B) Food-grade ginger $(50 \mathrm{mg} / \mathrm{ml})$ induced approximately $25 \%$ relaxation. The purified active components of crude ginger, [6]-gingerol, [8]gingerol, and [6]-shogaol, produced relaxation of $60-90 \%(100 \mu \mathrm{M})$. Interestingly, [10]-gingerol $(100 \mu \mathrm{M})$ did not significantly induce relaxation compared with vehicle control (DMSO, $0.2 \%$ ). ${ }^{*} p<0.05$, compared with vehicle. ${ }^{\$} p<0.05$, compared with food-grade ginger $(n=5-9)$. 
compared with DMSO vehicle control samples and food-grade ginger (Figure $1 \mathrm{~B} ; * P<0.05$, compared with DMSO; ${ }^{\$} P<0.05$, compared with food-grade ginger; $n=5-9)$. All relaxations began within 2 minutes of the addition of the compounds, and the percentage of relaxation achieved from the plateau of AChinduced contraction was calculated at 30 minutes.

The ability of individual ginger compounds to relax different contractile agonists was tested in epithelia-denuded guinea pig tracheas precontracted with either ACh $\left(\sim \mathrm{EC}_{50}\right)$ or the tachykinin, substance P (Sub P; $1 \mu \mathrm{M}$ ). In ASM precontracted with ACh, [6]-gingerol, [8]-gingerol, and [6]-shogaol (300 $\mu \mathrm{M}$ in all cases) induced relaxation of approximately $75 \%$, with [8]-gingerol and [6]-shogaol exhibiting complete relaxation $(\geqslant 100 \%$ ) within 30 minutes (Figure $2 \mathrm{~A} ; * P<0.05$, compared with control values; $n=8-11)$. The compound with the longest hydrocarbon side chain, [10]-gingerol $(300 \mu \mathrm{M})$, was less effective than the other compounds, and induced only $16 \%$ relaxation within the same time (not significant; Figure 2A; $n=8-11$ ). Tachykinins released from airway nerves serve as contractile agonists, and as such, the ability of gingerols and [6]-shogaol to relax Sub $\mathrm{P}$-contracted airways was investigated. These Sub $\mathrm{P}$-induced contractions are less stable than those with $\mathrm{ACh}$, showing spontaneous diminution in force over time. However, [6]-gingerol, [8]-gingerol, and [6]-shogaol $(300 \mu \mathrm{M})$ again exhibited potent relaxation of greater than $80 \%$, with [8]-
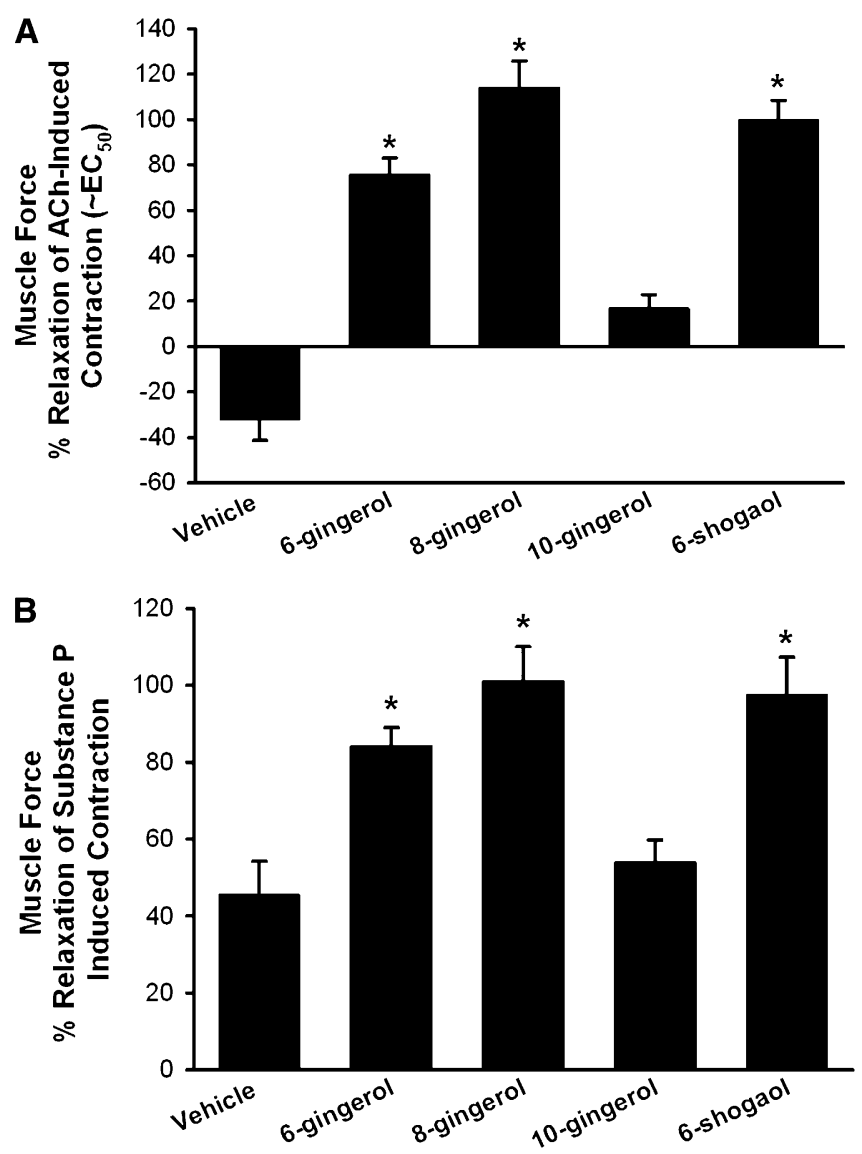

Figure 2. The relaxant effects of gingerols and [6]-shogaol persist, irrespective of a specific contractile agonist. $(A)$ [6]-gingerol, [8]-gingerol, and [6]-shogaol $(300 \mu \mathrm{M})$ significantly relaxed both acetylcholine-induced $\left(\sim \mathrm{EC}_{50}\right)$ and $(B)$ substance $\mathrm{P}$-induced $(1 \mu \mathrm{M})$ tracheal contractions in ex vivo guinea pig airway smooth muscle. Again, [10]-gingerol did not induce significant relaxation. $(A){ }^{*} P<0.001$, compared with vehicle $(n=8-11) .(B) * P<0.01$, compared with vehicle $(n=5-8)$. gingerol and [6]-shogaol inducing complete relaxation (Figure $2 \mathrm{~B} ; * P<0.05 ; n=5-8$ ).

Gingerols and shogaols are known activators of transient receptor potential vanilloid (TRPV) channels $(22,23)$. TRPV modulation can affect airway tone (24). As such, TRPV-dependent relaxation with [6]-gingerol, [8]-gingerol, and [6]-shogaol was investigated in guinea pig tracheal rings exposed to the TRPV antagonist capsazepine $(100 \mu \mathrm{M})$, contracted with an ACh of approximately $\mathrm{EC}_{50}$, as already described. In the presence of capsazepine, [6]gingerol, [8]-gingerol, and [6]-shogaol significantly relaxed ex vivo airway tissues, suggesting that TRPV1 is not involved in the observed relaxation induced by [6]-gingerol, [8]-gingerol, and [6]-shogaol (Figure E1 in the online supplement; $P<$ 0.05 , compared with DMSO control). TRPV blockade by capsazepine was confirmed by the absence of a capsaicin $(10 \mu \mathrm{M})$ induced contraction (data not shown).

\section{[8]-Gingerol and [6]-Shogaol Attenuate $\mathbf{G}_{\mathrm{q}^{-}}$-Coupled Receptor-Induced Increases in $\left[\mathrm{Ca}^{2+}\right]_{i}$}

In primary human ASM cells loaded with the ratiometric calcium indicator, Fura-2 AM, baseline calcium measurements were recorded but did not vary appreciably between wells. After a 15-minute pretreatment with [6]-gingerol, [8]-gingerol, [10]gingerol, and [6]-shogaol, $10 \mu \mathrm{M}$ of acetylcholine were added to Fura-2-loaded ASM cells. In cells receiving vehicle treatment (0.2\% DMSO), acetylcholine significantly increased $\left[\mathrm{Ca}^{2+}\right]_{\mathrm{i}}$. Cells treated with [10]-gingerol $(100 \mu \mathrm{M})$ demonstrated increases in $\left[\mathrm{Ca}^{2+}\right]_{\mathrm{i}}$ that approximated those of vehicle control samples. [6]gingerol, [8]-gingerol, and [6]-shogaol significantly decreased the acetylcholine-induced intracellular $\mathrm{Ca}^{2+}$ response, similar to the relaxation observed in ex vivo airway tissues (Figures $3 \mathrm{~A}$ and $3 \mathrm{~B} ; * P<0.05 ; n=8$ ). In separate experiments, [8]-gingerol and [6]-shogaol significantly attenuated bradykinin-induced increases in $\left[\mathrm{Ca}^{2+}\right]_{i}$, with [6]-shogaol completely abolishing a rise in $\left[\mathrm{Ca}^{2+}\right]_{\mathrm{i}}$. Here both [6]-gingerol and [10]-gingerol were ineffective at blocking bradykinin $\mathrm{Ca}^{2+}$ responses (Figures E2A and $\mathrm{E} 2 \mathrm{~B} ; * P<0.05 ; n=9)$.

\section{[6]-Gingerol, [8]-Gingerol, and [6]-Shogaol Prevent} $\mathrm{Ca}^{2+}$ Influx through L-Type $\mathrm{Ca}^{2+}$ Channels

In separate sets of experiments, cells pretreated with [6]-gingerol, [8]-gingerol, [10]-gingerol, and [6]-shogaol for 15 minutes were subsequently exposed to the L-type calcium channel opener, S-(-)-Bay K 8644 (Bay K, $10 \mu \mathrm{M})$. Cells treated with vehicle control $\left(0.2 \%\right.$ DMSO) showed an increase in $\left[\mathrm{Ca}^{2+}\right]_{i}$ upon the addition of Bay K, representing influx through L-type channels. Cells pretreated with [10]-gingerol did not differ from vehicle control samples. In this paradigm, the remaining three compounds, [6]-gingerol, [8]-gingerol, and [6]-shogaol, completely prevented calcium influx through L-type channels in cells exposed to Bay $\mathrm{K}$ (Figures E2C and E2D; $* P<0.05 ; n=9$ ).

\section{Gingerols and [6]-Shogaol Influence $\left[\mathrm{Ca}^{2+}\right]_{i}$ Handling in Human ASM}

In Fura-2-loaded human ASM cells, the addition of [6]-gingerol, [8]-gingerol, or [6]-shogaol alone $(100 \mu \mathrm{M}$ in all studies) induced an initial, transient increase in $\left[\mathrm{Ca}^{2+}\right]_{\mathrm{i}}$ that returned to baseline within 5 minutes. This phenomenon was previously reported with these compounds in different cell lines, but has not been characterized in ASM cells $(25,26)$, to the best of our knowledge. No increase in $\left[\mathrm{Ca}^{2+}\right]_{i}$ was observed with the addition of [10]-gingerol alone $(100 \mu \mathrm{M})$, compared with vehicle (Figure 4; $* P<0.05 ; n=9)$. 

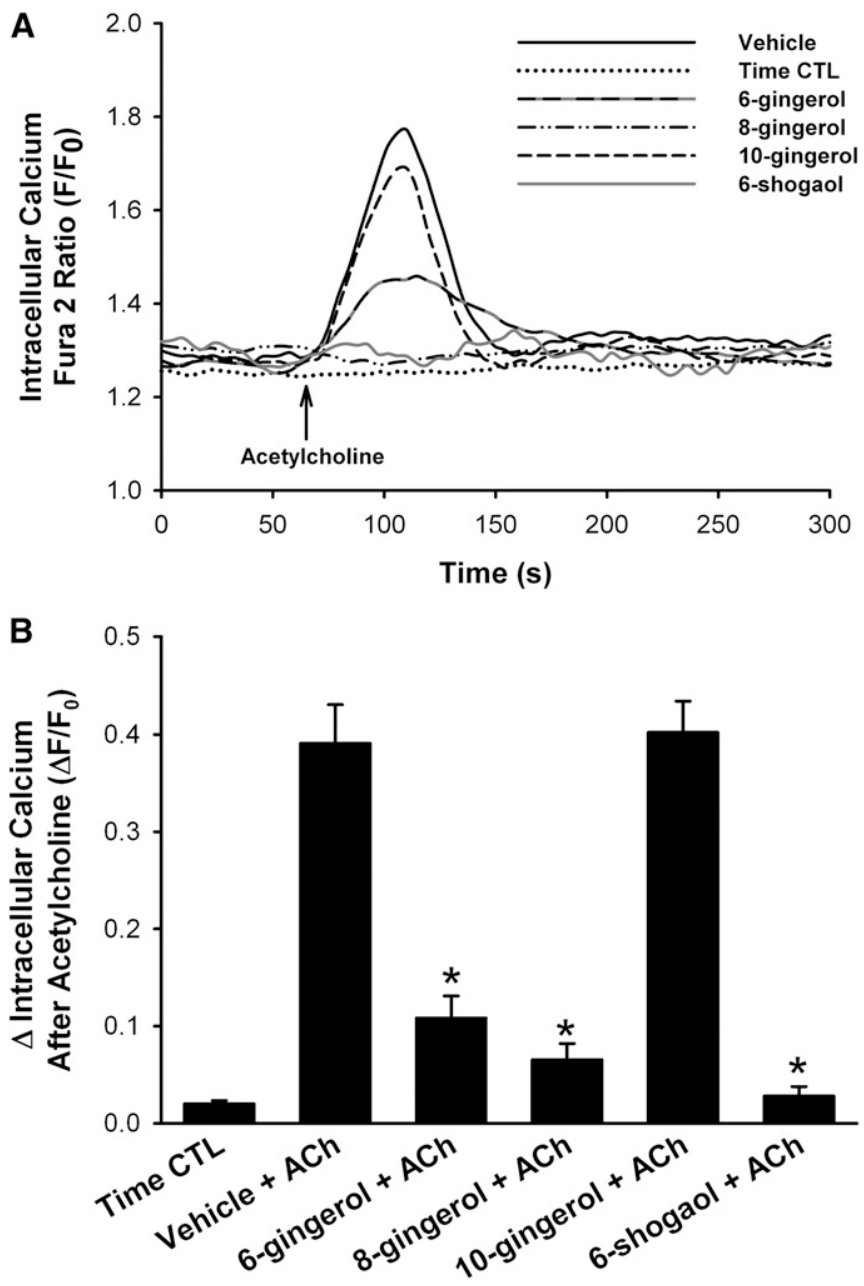

Figure 3. Ginger constituents block acetylcholine-induced increases of intracellular calcium $\left(\left[\mathrm{Ca}^{2+}\right]_{\mathrm{i}}\right)$ in human airway smooth muscle cells. $(A$ and $B$ ) In Fura-2-loaded human airway smooth muscle cells, pretreatment with $100 \mu \mathrm{M}$ gingerols or [6]-shogaol, followed by subsequent exposure to $10 \mu \mathrm{M}$ acetylcholine (ACh), revealed that [6]-gingerol, [8]-gingerol, and [6]-shogaol prevented increases in $\left[\mathrm{Ca}^{2+}\right]_{\mathrm{i}}$. This result was not observed with [10]-gingerol. (A) Representative tracing. (B) Summary bar graph. ${ }^{*} P<0.05$, compared with vehicle $(0.2 \%$ DMSO; $n=8)$. s, seconds. $C T L$, control; $F / F_{0}$, change in fura- 2 fluorescence ratio.

Initial Calcium Transients Involve Both $\mathrm{Ca}^{2+}$ Influx and Depletion of Sarcoplasmic Reticulum

Because the initial rise in calcium upon the addition of [6]-gingerol, [8]-gingerol, and [6]-shogaol reverted to baseline within minutes, we used pharmacologic inhibitors of various calcium mobilization pathways to investigate the source of this initial increase in $\mathrm{Ca}^{2+}$. The removal of extracellular calcium significantly attenuated the initial increase, suggesting a $\mathrm{Ca}^{2+}$ influx mechanism (Figure 5; $* P<0.05 ; n=6$ ). Moreover, pretreatment with $10 \mu \mathrm{M}$ nifedipine (an L-type calcium channel blocker) attenuated the response by approximately $50 \%$ (Figure $5 ; * P<0.05 ; n=6$ ). Pretreatment with $20 \mu \mathrm{M}$ ruthenium red (an antagonist of ryanodine receptors) significantly diminished the initial increase in calcium, suggesting a mechanism of intracellular store depletion (Figure 5; $* P<0.05$; $n=6$ ). Ruthenium red has also been reported to block TRPV channels. To investigate the involvement of TRPV channel activation in the transient calcium response, the TRPV channel antagonist, capsazepine $(10 \mu \mathrm{M})$, was added to cells before the addition of ginger compounds. Pretreatment with capsazepine attenuated the response by approximately $50 \%$, similar to that of

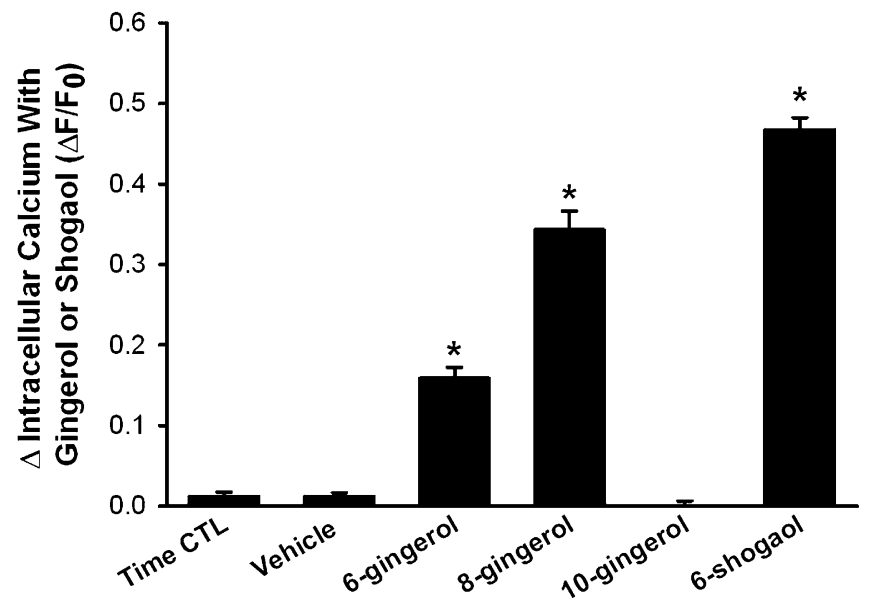

Figure 4. Ginger constituents cause a transient rise in $\left[\mathrm{Ca}^{2+}\right]_{i}$. In Fura2-loaded cells, the addition of [6]-gingerol, [8]-gingerol, or [6]-shogaol alone $(100 \mu \mathrm{M})$ caused an initial transient increase in $\left[\mathrm{Ca}^{2+}\right]_{i}$. This response returned to baseline within 5 minutes. No change in $\left[\mathrm{Ca}^{2+}\right]_{\mathrm{i}}$ was observed with [10]-gingerol $(100 \mu \mathrm{M}) .{ }^{*} P<0.05$, compared with vehicle $(n=9)$.

nifedipine, further implicating a $\mathrm{Ca}^{2+}$ influx mechanism (Figure 5; $* P<0.05 ; n=6)$. Interestingly, pretreatment with the inositol triphosphate $\left(\mathrm{IP}_{3}\right)$ receptor antagonist, xestospongin $\mathrm{C}(1 \mu \mathrm{M})$, did not affect the calcium responses of these compounds (Figure $5 ; * P<0.05 ; n=6$ ).

No increases in ASM force were detected upon the addition of these compounds in organ bath experiments, further confirming the transient nature of these initial $\mathrm{Ca}^{2+}$ responses (data not shown).

\section{[6]-Shogaol Attenuates Bradykinin-Induced Synthesis of $\mathrm{IP}_{3}$}

Given our results that [8]-gingerol and [6]-shogaol greatly ([8]gingerol) or completely ([6]-shogaol) attenuated a bradykinininduced $\mathrm{Ca}^{2+}$ response in human ASM cells, we investigated the effects of these compounds on $\mathrm{IP}_{3}$ synthesis in response to bradykinin. No differences in basal $\mathrm{IP}_{3}$ measurements were

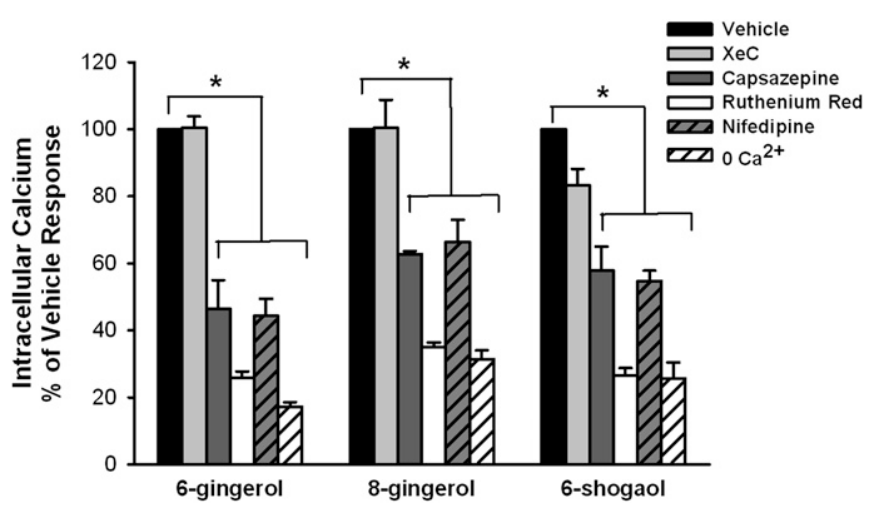

Figure 5. Initial transient increases in $\left[\mathrm{Ca}^{2+}\right]_{\mathrm{i}}$ caused by ginger components are attributable to influx and store depletion. In airway smooth muscle cells, the initial $\left[\mathrm{Ca}^{2+}\right]_{i}$ spike was attenuated by the L-type $\mathrm{Ca}^{2+}$ channel blocker, nifedipine $(10 \mu \mathrm{M})$, the transient receptor potential vanilloid channel blocker, capsazepine $(100 \mu \mathrm{M})$, the ryanodine receptor antagonist, ruthenium red $(20 \mu \mathrm{M})$, and the removal of external $\mathrm{Ca}^{2+}$. It was not attenuated by the inositol triphosphate receptor antagonist, xestospongin $\mathrm{C}(\mathrm{XeC}, 1 \mu \mathrm{M}) .{ }^{*} P<0.05(n=7-8)$. 
observed between vehicle and ginger component-treated cells. Bradykinin-induced inositol phosphate synthesis was significantly attenuated $(80 \%)$ in cells pretreated with $100 \mu \mathrm{M}$ [6]-shogaol. Neither [6]-gingerol, [8]-gingerol, nor [10]-gingerol exerted any effects on the bradykinin- induced synthesis of $\mathrm{IP}_{3}$ (Figure 6; $* P<0.05 ; n=3-8)$.

Previous groups have shown a dose-dependent cytotoxicity associated with [6]-shogaol in the concentration range of our study (26). As such, a 3-(4,5-dimethylthiazol-2-Yl)-2,5-diphenyltetrazolium bromide toxicity assay was performed to assess whether or not decreases in $\mathrm{IP}_{3}$ synthesis with [6]-shogaol pretreatment were related to cell death. No change in formazan production was evident among vehicle control samples, [6]-gingerol, [8]gingerol, or [6]-shogaol (100 $\mu \mathrm{M}$; 1 hour), whereas $100 \mathrm{mM}$ hydrogen peroxide served as a positive control of cell toxicity (Figure E3; ${ }^{*} P<0.05 ; n=4$ ).

\section{Inhalation of [8]-Gingerol Prevents Methacholine-Induced Hyperresponsiveness in Mice}

[8]-gingerol or vehicle control (0.1\% DMSO) was aerosolized to naively hyperresponsive male $\mathrm{A} / \mathrm{J}$ mice to test the efficacy of ginger constituents in mediating methacholine-induced changes in airway responsiveness. A single nebulization of $100 \mu \mathrm{M}$ [8]-gingerol lasting 10 seconds, 15 minutes before the start of a standard methacholine challenge, attenuated changes in central airway resistance (Newtonian resistance) at 37.5 and $50 \mathrm{mg} / \mathrm{ml} \mathrm{meth-}$ acholine, compared with vehicle control samples (Figure 7; $n=$ $6-11, * P<0.05)$. Neither [8]-gingerol nor vehicle nebulization increased airway resistance over baseline.

\section{DISCUSSION}

We have shown for the first time that isolated components of ginger (Zingiber officinale) directly relax precontracted ASM from both guinea pigs and humans within 30 minutes. In addition, [6]shogaol and [8]-gingerol comprise the most potent constituents, resulting in $\geqslant 100 \%$ relaxation. These effects are specific to smooth muscle because they occur in the absence of epithelia and

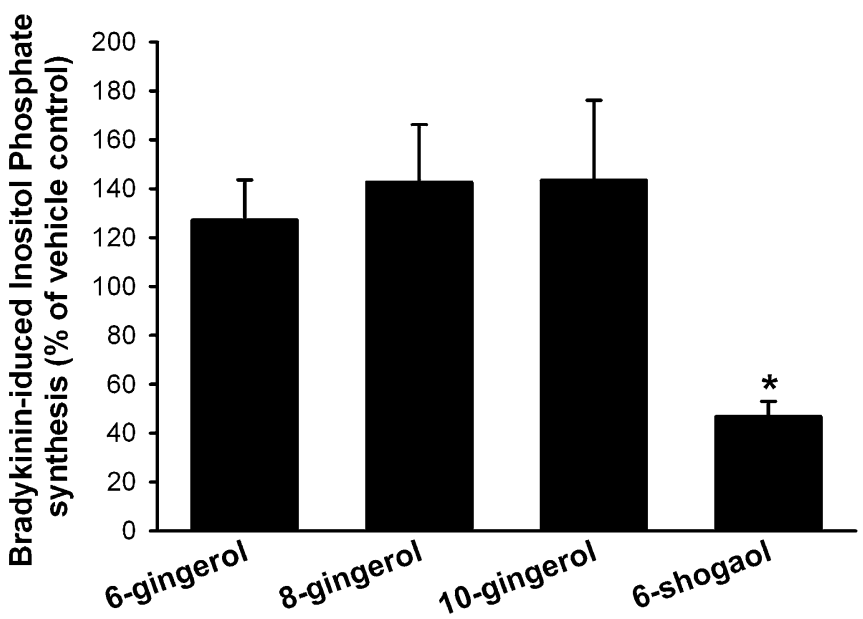

Figure 6. [6]-shogaol decreases the synthesis of inositol phosphate. After a 15-minute preincubation with ginger constituents $(100 \mu \mathrm{M})$ or vehicle $(0.1 \%$ or $0.2 \%$ DMSO), $10 \mu \mathrm{M}$ of bradykinin were added for an additional 30 minutes before the extraction and column separation of newly synthesized total $\left[{ }^{3} \mathrm{H}\right]$-inositol phosphates. Only [6]-shogaol significantly attenuated the production of inositol phosphate. Data are expressed as a percentage of vehicle control values. ${ }^{*} P<0.05$, compared with vehicle $(n=3-8)$.

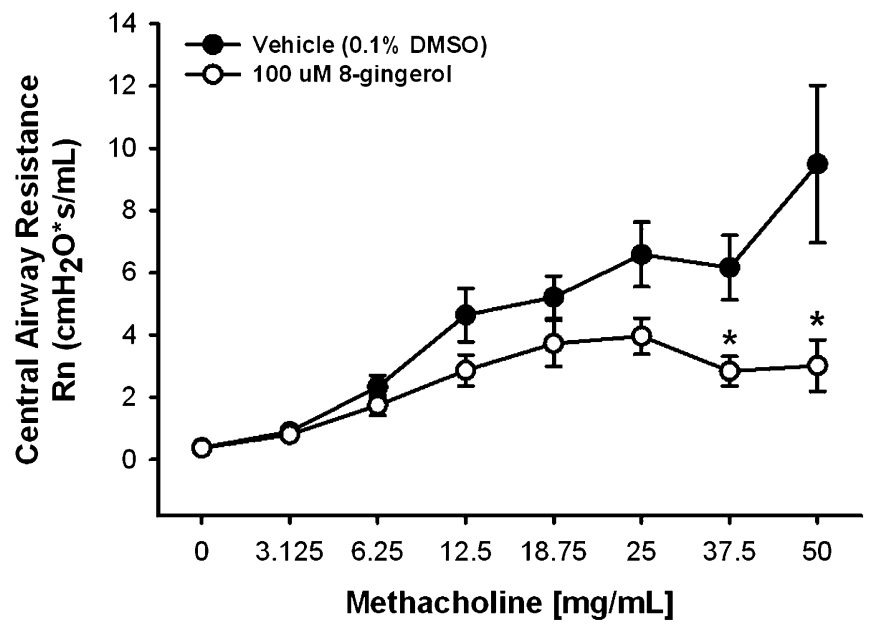

Figure 7. The nebulization of [8]-gingerol prevents hyperresponsiveness to methacholine. In male $\mathrm{A} / \mathrm{J}$ mice, increasing concentrations of methacholine $(\mathrm{MCh})$ result in increases in central airway resistance (Newtonian resistance, $\mathrm{Rn}$ ) measured using a constant phase model on a Flexivent FX1 module. Increases in resistance at 37.5 and $50 \mathrm{mg} / \mathrm{ml} \mathrm{MCh}$ were attenuated in animals that received a 10-second nebulization of $100 \mu \mathrm{M}$ [8]-gingerol, 15 minutes before MCh challenge. ${ }^{*} P<0.05$, compared with vehicle $(n=6-11)$.

in the presence of airway nerve blockade. Moreover, these effects are independent of the contractile agonist used, because the relaxation of both ACh-induced and Sub P-induced contractions was demonstrated. Furthermore, [8]-gingerol attenuates airway hyperresponsiveness in naive mice when nebulized before methacholine challenge. This is the first study where an active component of ginger was delivered via inhalation in an in vivo experiment assessing airway mechanics. Although the beneficial effects of ginger on cough and respiratory infection have been reported in the literature $(11,27)$, this is the first time that the mechanisms of action for individual active components of ginger have been investigated in isolated human ASM cells and ex vivo airway smooth muscle. We have shown that [8]gingerol and [6]-shogaol decrease calcium responses to the $\mathrm{G}_{\mathrm{q}}$-coupled receptor agonists, bradykinin and acetylcholine, and also reduce $\mathrm{Ca}^{2+}$ influx through L-type calcium channels. Interestingly, side-chain length and saturation seem to affect the potency of these compounds, with the unsaturated form, [6]-shogaol, showing the highest efficacy, whereas [10]-gingerol, the compound with the longest side chain, was ineffective at relaxing airways.

In a recent, systematic review of herbal treatments of asthma, Singh and colleagues discussed the growing trend of herbal therapies for asthma and the increasing demand for research on the use of CAM in asthma (1). Here, ginger was not among the phytotherapeutics discussed, although it has been implicated in alleviating other ailments and diseases, including nausea and emesis in pregnancy, hypertension, cancer, dyspepsia, and diarrhea $(12,13,28-30)$. Only three studies have examined the physiologic effects of ginger on the airway, and in all of these studies, a crude ginger extract was used. Crude ginger extract showed bronchodilator activity and inhibited ACh-induced contraction and $\mathrm{Ca}^{2+}$ transients in guinea pigs $(10,31)$, and intraperitoneal injections attenuated LPS-induced hyperresponsiveness in rat tracheas (32). Although these studies are insightful and confirmatory of the bronchodilatory properties of ginger, and loosely imply $\mathrm{Ca}^{2+}$ influx through the plasma membrane, they neither dissect the individual active components responsible for the observed bronchodilation nor attempt to elucidate further 
the complex intracellular signaling mechanisms ultimately responsible for airway relaxation.

Airway tone is determined by both bronchoconstriction and bronchodilation, with $\left[\mathrm{Ca}^{2+}\right]_{\mathrm{i}}$ constituting a primary determinant. Increases in $\left[\mathrm{Ca}^{2+}\right]_{\mathrm{i}}$ in ASM after bronchoconstrictor stimulation are attributed to calcium depletion from the SR, as well as calcium influx through the plasma membrane $(18,33)$. Calcium influx can occur through voltage-gated (34) and receptoroperated (35) channels, the sodium-calcium exchanger (reverse mode) $(36,37)$, store-operated calcium entry channels $(38-40)$, and transient receptor potential (TRP) channels (41-43). Both TRPC and TRPV channels have gained attention for modulating calcium influx in ASM $(41,44)$, whereas TRPV1 antagonists relax human small airways (24). In rat dorsal root ganglia, gingerols (specifically, [6]-gingerol and [8]-gingerol) were shown to comprise a novel class of TRPV1 agonists. These data conflict with our observation that [6]-gingerol, [8]-gingerol, and [6]-shogaol relax ASM. In mechanistic studies of ASM cells, the blockade of TRPV1 channels with capsazepine attenuated the transient calcium signal induced by [6]-gingerol, [8]-gingerol, and [6]shogaol. However, the relaxant effect of these compounds persisted in tracheal muscle pretreated with capsazepine. Thus, in ASM, the relaxation induced by [6]-gingerol, [8]-gingerol, and [6]-shogaol does not appear to involve a TRPV1-dependent mechanism. This is supported by work performed in guinea pig ileum, where the relaxant effects of [6]-gingerol were not attenuated with capsazepine, confirming a downstream signaling event responsible for relaxation in this tissue (28). Interestingly, Skogvall and colleagues characterized a novel TRPV1 antagonist that relaxed ASM independent of TRPV1 antagonism, thereby suggesting another site of action for compounds that can bind TRPV1 receptors (24).

Our present work agrees with that of Ghayur and colleagues (10) in establishing the relaxing effects of crude, food-grade ginger. However, novel aspects of the present work include the investigation of [6]-gingerol, [8]-gingerol, [10]-gingerol, and [6]-shogaol as unique bronchodilating compounds. In addition, we have examined in detail the role of plasma membrane $\mathrm{Ca}^{2+}$ influx through both L-type $\mathrm{Ca}^{2+}$ channels and TRPV1 channels, as well as the effects by isolated components of ginger on ryanodine and inositol triphosphate receptors $\left(\mathrm{IP}_{3} \mathrm{R} ; \mathrm{SR}\right.$ calcium channels). Similar to previous studies (10) showing that crude ginger inhibits calcium transients induced by $\mathrm{ACh}$, we were able to show that [6]-gingerol, [8]-gingerol, and [6]-shogaol prevent increases in intracellular calcium attributable to acetylcholine in primary human ASM cells, and also prevent calcium influx through L-type calcium channels.

The initial calcium spike observed in Fura-2 calcium imaging studies suggests a mechanism of calcium-induced calcium release, followed by a subsequent blockade of both L-type channels and ryanodine receptors. Calcium store depletion and refilling were previously shown to be responsible for force maintenance in the airway (45). By activating and subsequently blocking ryanodine receptors, [6]-gingerol, [8]-gingerol, and [6]-shogaol cause an initial calcium transient that resolves within minutes, but more importantly, prevent further SR calcium depletion in two ways, by (1) ryanodine receptor blockade, and (2) the inhibition of $\mathrm{IP}_{3}$ synthesis in the case of [6]-shogaol.

Using the ryanodine receptor antagonist, ruthenium red, we were able to blunt the acute calcium effects of [6]-gingerol, [8]-gingerol, and [6]-shogaol in human ASM cells. Work by Chen and colleagues in human oral cancer cells showed that an acute calcium spike attributable to [6]-shogaol was blocked by pretreatment with a sarcoendoplasmic reticulum calcium-ATPase inhibitor, thapsigargin (26). Furthermore, in guinea pig atria, the inotropic effect of [6]-gingerol was blocked by ryanodine (29), indicating that
SR-calcium depletion is likely an important step in the signaling cascade of these compounds.

The importance of SR-calcium depletion was realized during the second phase of the assay, when bradykinin, a contractile agonist that depletes SR-calcium via $\mathrm{IP}_{3} \mathrm{R}$ activation subsequent to $\mathrm{IP}_{3}$ generation, failed to induce a calcium increase in cells pretreated with [8]-gingerol and [6]-shogaol, but not [6]-gingerol or [10]-gingerol. This would suggest that [8]-gingerol and [6]shogaol activate and subsequently inhibit ryanodine receptor activation, but not $\mathrm{IP}_{3} \mathrm{R}$ directly, because xestospongin $\mathrm{C}$ exerted no effect on these compounds ([6]-gingerol, [8]-gingerol, and [6]shogaol). This alteration of SR-calcium handling and impaired calcium influx through L-type calcium channels likely plays a role in the observed relaxation of isolated airways contracted with ACh or Sub P.

Taken together, these data comprise the first to show mechanistic evidence for the bronchorelaxant properties of ginger, and to confirm that [6]-gingerol, [8]-gingerol, and [6]-shogoal, but not [10]-gingerol, are the active components of this phytotherapeutic responsible for bronchorelaxation. In addition to relaxing precontracted ex vivo ASM, inhalation of the active component [8]-gingerol protected against methacholine-induced hyperresponsiveness in an in vivo murine model. Given that as many as $40 \%$ of patients with asthma self-treat their asthma symptoms with herbal remedies, it is increasingly important to understand the active components of these phytotherapies, their mechanisms of action, and potential interactions (positive and negative) with current asthma therapeutics. Furthermore, systematic analyses of the mechanisms of action responsible for the bronchorelaxant properties of ginger constituents will facilitate the acceptance of phytotherapeutics in the medical and basic science communities, and will open new avenues for CAM therapies in asthma and other airway diseases.

Author disclosures are available with the text of this article at www.atsjournals.org.

Acknowledgments: The authors acknowledge the insights of Dr. Alison Rinderspracher and her contributions regarding the chemical structure and activity sites of the ginger constituents.

\section{References}

1. Singh BB, Khorsan R, Vinjamury SP, Der-Martirosian C, Kizhakkeveettil A, Anderson TM. Herbal treatments of asthma: a systematic review. $J$ Asthma 2007;44:685-698.

2. Kao ST, Chang CH, Chen YS, Chiang SY, Lin JG. Effects of DingChuan-Tang on bronchoconstriction and airway leucocyte infiltration in sensitized guinea pigs. Immunopharmacol Immunotoxicol 2004;26: 113-124.

3. Li A, Xie Y, Qi F, Li J, Wang P, Xu S, Zhao L. Anti-virus effect of traditional Chinese medicine $\mathrm{Yi}-\mathrm{Fu}$-Qing granule on acute respiratory tract infections. Biosci Trends. 2009;3:119-123.

4. Mali RG, Dhake AS. A review on herbal antiasthmatics. Orient Pharm Exp Med 2011;11:77-90.

5. Park HS, Kim SR, Kim JO, Lee YC. The roles of phytochemicals in bronchial asthma. Molecules 2010;15:6810-6834.

6. Clement YN, Williams AF, Aranda D, Chase R, Watson N, Mohammed R, Stubbs O, Williamson D. Medicinal herb use among asthmatic patients attending a specialty care facility in Trinidad. BMC Complement Altern Med 2005;5:3.

7. Rivera JO, Hughes HW, Stuart AG. Herbals and asthma: usage patterns among a border population. Ann Pharmacother 2004;38:220-225.

8. Chang HC, Gong CC, Chen JL, Mak OT. Inhibitory effects of inhaled complex traditional Chinese medicine on early and late asthmatic responses induced by ovalbumin in sensitized guinea pigs. BMC Complement Altern Med 2011;11:80.

9. Wen MC, Wei CH, Hu ZQ, Srivastava K, Ko J, Xi ST, Mu DZ, Du JB, Li $\mathrm{GH}$, Wallenstein S, et al. Efficacy and tolerability of anti-asthma herbal medicine intervention in adult patients with moderate-severe allergic asthma. J Allergy Clin Immunol 2005;116:517-524. 
10. Ghayur MN, Gilani AH, Janssen LJ. Ginger attenuates acetylcholineinduced contraction and $\mathrm{Ca}^{2+}$ signalling in murine airway smooth muscle cells. Can J Physiol Pharmacol 2008;86:264-271.

11. Qidwai W, Alim SR, Dhanani RH, Jehangir S, Nasrullah A, Raza A. Use of folk remedies among patients in Karachi Pakistan. J Ayub Med Coll Abbottabad 2003;15:31-33.

12. Chrubasik S, Pittler MH, Roufogalis BD. Zingiber rhizoma: a comprehensive review on the ginger effect and efficacy profiles. Phytomedicine 2005; 12:684-701.

13. Borrelli F, Capasso R, Pinto A, Izzo AA. Inhibitory effect of ginger (Zingiber officinale) on rat ileal motility in vitro. Life Sci 2004;74: 2889-2896.

14. Bhattarai S, Tran VH, Duke CC. The stability of gingerol and shogaol in aqueous solutions. J Pharm Sci 2001;90:1658-1664.

15. Govindarajan VS. Ginger-chemistry, technology, and quality evaluation: part 2. Crit Rev Food Sci Nutr 1982;17:189-258.

16. Zick SM, Djuric Z, Ruffin MT, Litzinger AJ, Normolle DP, Alrawi S Feng MR, Brenner DE. Pharmacokinetics of 6-gingerol, 8-gingerol, 10-gingerol, and 6-shogaol and conjugate metabolites in healthy human subjects. Cancer Epidemiol Biomarkers Prev 2008;17:1930-1936.

17. Gallos G, Yim P, Chang S, Zhang Y, Xu D, Cook JM, Gerthoffer WT, Emala CW. Targeting the restricted alpha-subunit repertoire of airway smooth muscle $\mathrm{GABA}_{\mathrm{A}}$ receptors augments airway smooth muscle relaxation. Am J Physiol Lung Cell Mol Physiol 2012;302:L248-L256.

18. Townsend EA, Thompson MA, Pabelick CM, Prakash YS. Rapid effects of estrogen on intracellular $\mathrm{Ca}^{2+}$ regulation in human airway smooth muscle. Am J Physiol Lung Cell Mol Physiol 2010;298:L521-L530.

19. Gleason NR, Gallos G, Zhang Y, Emala CW. Propofol preferentially relaxes neurokinin receptor-2-induced airway smooth muscle contraction in guinea pig trachea. Anesthesiology 2010;112:1335-1344.

20. Hotta K, Emala CW, Hirshman CA. TNF-alpha upregulates $\mathrm{G}_{\mathrm{i}}$ alpha and $\mathrm{G}_{\mathrm{q}}$ alpha protein expression and function in human airway smooth muscle cells. Am J Physiol Lung Cell Mol Physiol 1999;276:L405-L411.

21. Jooste E, Zhang Y, Emala CW. Rapacuronium preferentially antagonizes the function of M2 versus M3 muscarinic receptors in guinea pig airway smooth muscle. Anesthesiology 2005;102:117-124.

22. Riera CE, Menozzi-Smarrito C, Affolter M, Michlig S, Munari C, Robert F, Vogel H, Simon SA, le Coutre J. Compounds from Sichuan and Melegueta peppers activate, covalently and non-covalently, TRPA1 and TRPV1 channels. Br J Pharmacol 2009;157:1398-1409.

23. Morera E, De Petrocellis L, Morera L, Moriello AS, Nalli M, Di Marzo V, Ortar G. Synthesis and biological evaluation of [6]-gingerol analogues as transient receptor potential channel TRPV1 and TRPA1 modulators. Bioorg Med Chem Lett 2012;22:1674-1677.

24. Skogvall S, Dalence-Guzman MF, Berglund M, Svensson K, Mesic A, Jonsson P, Persson CG, Sterner O. Discovery of a potent and longacting bronchorelaxing capsazepinoid, RESPIR 4-95. Pulm Pharmacol Ther 2008;21:125-133.

25. Chen CY, Chen CH, Kung CH, Kuo SH, Kuo SY. [6]-gingerol induces $\mathrm{Ca}^{2+}$ mobilization in Madin-Darby canine kidney cells. J Nat Prod 2008;71:137-140.

26. Chen CY, Yang YH, Kuo SY. Effect of [6]-shogaol on cytosolic $\mathrm{Ca}^{2+}$ levels and proliferation in human oral cancer cells (OC2). J Nat Prod 2010;73:1370-1374.

27. Akoachere JF, Ndip RN, Chenwi EB, Ndip LM, Njock TE, Anong DN. Antibacterial effect of Zingiber officinale and Garcinia kola on respiratory tract pathogens. East Afr Med J 2002;79:588-592.
28. Abdel-Aziz H, Windeck T, Ploch M, Verspohl EJ. Mode of action of gingerols and shogaols on 5-HT3 receptors: binding studies, cation uptake by the receptor channel and contraction of isolated guinea-pig ileum. Eur J Pharmacol 2006;530:136-143.

29. Ghayur MN, Gilani AH, Afridi MB, Houghton PJ. Cardiovascular effects of ginger aqueous extract and its phenolic constituents are mediated through multiple pathways. Vascul Pharmacol 2005;43: 234-241.

30. Chen JC, Huang LJ, Wu SL, Kuo SC, Ho TY, Hsiang CY. Ginger and its bioactive component inhibit enterotoxigenic Escherichia coli heat-labile enterotoxin-induced diarrhea in mice. J Agric Food Chem 2007;55: 8390-8397.

31. Ghayur M, Gilani A. Inhibitory activity of ginger rhizome on airway and uterine smooth muscle preparations. Eur Food Res Technol 2007;224: 477-481.

32. Aimbire F, Penna SC, Rodrigues M, Rodrigues KC, Lopes-Martins RA, Sertie JA. Effect of hydroalcoholic extract of Zingiber officinalis rhizomes on LPS-induced rat airway hyperreactivity and lung inflammation. Prostaglandins Leukot Essent Fatty Acids 2007;77:129-138.

33. Sanders KM. Invited review: mechanisms of calcium handling in smooth muscles. J Appl Physiol 2001;91:1438-1449.

34. Worley JF III, Kotlikoff MI. Dihydropyridine-sensitive single calcium channels in airway smooth muscle cells. Am J Physiol Lung Cell Mol Physiol 1990;259:L468-L480.

35. Murray RK, Kotlikoff MI. Receptor-activated calcium influx in human airway smooth muscle cells. J Physiol 1991;435:123-144.

36. Sathish V, Delmotte PF, Thompson MA, Pabelick CM, Sieck GC, Prakash YS. Sodium-calcium exchange in intracellular calcium handling of human airway smooth muscle. PLoS ONE 2011;6:e23662.

37. Hirota S, Janssen LJ. Store-refilling involves both L-type calcium channels and reverse-mode sodium-calcium exchange in airway smooth muscle. Eur Respir J 2007;30:269-278.

38. Sathish V, Abcejo AJ, Thompson MA, Sieck GC, Prakash YS, Pabelick CM. Caveolin-1 regulation of store-operated $\mathrm{Ca}^{2+}$ influx in human airway smooth muscle. Eur Respir J 2012;40:470-478.

39. Prakash YS, Iyanoye A, Ay B, Sieck GC, Pabelick CM. Store-operated $\mathrm{Ca}^{2+}$ influx in airway smooth muscle: interactions between volatile anesthetic and cyclic nucleotide effects. Anesthesiology 2006;105:976-983.

40. Venkatachalam K, van Rossum DB, Patterson RL, Ma HT, Gill DL. The cellular and molecular basis of store-operated calcium entry. Nat Cell Biol 2002;4:E263-E272.

41. Gosling M, Poll C, Li S. TRP channels in airway smooth muscle as therapeutic targets. Naunyn Schmiedebergs Arch Pharmacol 2005; 371:277-284.

42. Dietrich A, Chubanov V, Kalwa H, Rost BR, Gudermann T. Cation channels of the transient receptor potential superfamily: their role in physiological and pathophysiological processes of smooth muscle cells. Pharmacol Ther 2006;112:744-760.

43. Jia Y, Wang X, Varty L, Rizzo CA, Yang R, Correll CC, Phelps PT, Egan RW, Hey JA. Functional TRPV4 channels are expressed in human airway smooth muscle cells. Am J Physiol Lung Cell Mol Physiol 2004; 287:L272-L278.

44. Li S, Westwick J, Poll C. Transient receptor potential (TRP) channels as potential drug targets in respiratory disease. Cell Calcium 2003; 33:551-558.

45. Coburn RF, Baron CB. Coupling mechanisms in airway smooth muscle. Am J Physiol Lung Cell Mol Physiol 1990;258:L119-L133. 